\title{
Kompetensi Sosial Kepala Madrasah Dan Guru Dalam Meningkatkan Mutu Pendidikan Islam
}

\author{
Jasman \\ Pascasarjana Sekolah Tinggi Agama Islam Negeri (STAIN) Curup \\ Jasman.curup2017@gmail.com
}

\begin{abstract}
Abstrak
Karakteristik guru yang memiliki kompetensi sosial adalah berkomunikasi secara santun dan bergaul secara efektif. Kompetensi sosial mengharuskan guru memiliki kemampuan komunikasi dengan siswa.

Ditinjau dari jenis datanya pendekatan penelitian yang digunakan dalam penelitian ini adalah pendekatan kualitatif. Adapun jenis pendekatan penelitian ini adalah deskriptif. Penelitian deskriptif yaitu penelitian yang berusaha untuk menuturkan pemecahan masalah yang ada sekarang berdasarkan data-data.

Adapun Manajemen Kepala Madrasah Dalam Meningkatkan Kompetensi Sosial Guru, yaitu dengan mendengarkan ide / saran dari para guru, Sosialisasi, mengemukakan keinginan dan menjelaskan keinginan, memberikan masukan dan berusaha memecahkan masalah guru, Membagi tugas secara bersama (tidak monopoli), memberikan teladan, bertindak sesuai dengan kemampuan guru, memberikan perhatian yang lebih terhadap yang rajin, dan Mengikuti pelatihan berkaitan dengan kompetensi sosial guru.

Secara keseluruhan dan umum kinerja guru yang menjadi kendala adalah cara mengajar guru kurang disukai/bahkan tidak disukai, bimbingan dan penyuluhan dari guru kurang maksimal, penguasaan guru akan ilmu yang harus disampaikan kurang, cara penyampaian materi yang monoton dan kurang variatif, kurangnya pemahaman guru tentang psikologi anak, perhatian guru tentang latar belakang dan kebutuhan anak kurang, kurang adanya konsep perencanaan yang baik dalam penyusunan program-program untuk memajukan lembaga yang ditanganinya, kepribadian guru yang kurang matang, dan minimnya kreatifitas dan inovasi untuk mengatasi berbagai hambatan yang terjadi dalam lembaga.
\end{abstract}

Kata kunci: Manajemen Kepala Madrasah; Kompetensi Sosial.

\section{Pendahuluan}

Manusia adalah makhluk sosial, yang tak dapat hidup sendiri tanpa melakukan interaksi dengan individu lainnya. Pada hakikatnya tiap individu tidak ada yang sempurna, masing-masing memiliki kekurangan dan kelebihan. Kekurangan tersebut akan terpenuhi manakala melakukan interaksi sosial. 
Dalam melakukan interaksi sosial, seluruh anggota masyarakat menciptakan suatu system nilai dan norma. Sistem nilai dan norma tersebut berfungsi sebagai acuan/pedoman dalam melakukan segala aktivitas di masyarakat. Tanpa adanya norma, warga masyarakat cenderung melakukan peran sosial semaunya sendiri. Hal tersebut akan berdampak timbulnya ketidakseimbangan sosial.

Sistem norma yang telah ada tidak serta merta akan membentuk masyarakat yang tertib, seimbang dan harmonis, namun diperlukan adanya kesadaran sosial seluruh anggota masyarakat. ${ }^{1}$ Kesadaran sosial ditunjukkan dalam beberapa hal berikut ini $:^{2}$

1. Adanya kesadaran bahwa manusia tidak dapat hidup sendiri tanpa orang lain.

2. Adanya kesadaran bahwa setiap manusia yang hidup dimasyarakat harus mematuhi system norma dan nilai yang berlaku di masyarakatnya.

3. Adanya kesadaran bahwa seluruh anggota masyarakat memiliki tanggung jawab dalam menciptakan keseimbangan, keserasian dan keharmonisan hidup bermasyarakat.

4. Adanya kesadaran bahwa dimasyarakat multikultur, seluruh anggota masyarakat harus memahami setiap perbedaan yang ada.

5. Adanya kesadaran bahwa dalam memenuhi kebutuhan hidup (primer, sekunder, dan lain-lain) harus memperhatikan beberapa aspek di masyarakat, sehingga tidak mer 1 lkan benturan kepentingan, peran dan sebagainya.

6. Adanya kesadaran bahwa masing-masing individu melaksanakan status dan peran yang disandangnya dengan penuh tanggung jawab dengan memperhatikan kaidah yang berlaku.

Dalam Kamus Besar Bahasa Indonesia, kesadaran sosial adalah kesadaran seseorang secara penuh akan hak dan kewajiban sebagai anggota masyarakat. ${ }^{3}$ Berdasarkan pengertian ini, konsep kesadaran sosial memiliki dua keutamaan hidup manusia yang tidak dapat dipisahkan antara satu dengan yang lain, yakni hak dan kewajiban seorang pribadi manusia sosial.

Dengan kesadaran akan haknya yang seperti itu, seorang pribadi manusia mampu untuk memahami sebuah realitas dalam masyarakat sosial. Pemahaman

\footnotetext{
${ }^{1}$ Kesadaran sosial adalah representasi jiwa seseorang akan dirinya sendiri dan orang lain. Wegner, Social Awareness, Jurnal Sheldon. 1982.

${ }^{2}$ Namira Suade kemudian mengemukakan bahwa kesadaran sosial berhubungan dengan kewaspadaan seseorang terhadap situasi sosial yang dialami oleh diri sendiri dan orang lain, sehingga individu dapat menjadi tahu dan menyadari hal-hal yang terjadi di sekelilingnya. Lihat Namira Suade Bachrie, Hubungan Jenis Sekolah dalam Kesadaran Sosial, Jurnal FPSI UI, 2009.

${ }^{3}$ Tim Penyusun KBBI, $1988: 765$
} 
akan hal ini memampukan untuk menyampaikan dan memaparkan kepada orang lain, sehingga kesadaran ini tidak hanya menjadi kesadaran personal melainkan menjadi kesadaran komunal (bersama). Dalam hal ini, setiap pribadi manusialah yang menjadi aktor dalam realitas masyarakat untuk melakukan setiap aktivitas yang mengarah pada penataan hidup masyarakat yang lebih baik.

Setiap pribadi manusia adalah pemegang peranan yang paling utama dalam realitas kehidupan masyarakat sosial. Seperti yang diungkapkan oleh Dr. William Chang, OFMCap dalam buku Pengantar Teologi Moral bahwa seorang manusia adalah subjek hak dan kewajiban, sebab manusia adalah pemegang hak dan kewajiban. Sebagai pemegang hak, manusia mampu melakukan sesuatu bagi pribadinya atau bagi orang lain. Selanjutnya Chang juga memberi pemahaman tentang konsep hak pribadi manusia. Hak itu dipandang sebagai ruang yang menjamin otonomi manusia, hak itu memungkinkan manusia untuk mengambil keputusan dan mengendalikan dirinya. ${ }^{4}$

Manusia dapat menyalahgunakan haknya sehingga tidak memenuhi kewajibannya sebagai pribadi dan dalam hubungan dengan sesama. Dan tidak jarang seseorang menitikberatkan hak pribadinya sehingga melupakan hak dasar orang lain yakni kewajiban untuk menghargai hak-hak orang lain. Dengan demikian, kesadaran sosial tidak hanya dimiliki melainkan diterapkan dalam hidup nyata. Kesadaran sosial seseorang akan hak dan kewajiban harus disadarkan dalam hidup bermasyarakat, sehingga tumbuh kehidupan yang lebih baik, aman, tenteram dan sejahtera. ${ }^{5}$

Kesadaran sosial juga dijelaskan dalam hadis Nabi Muhammad SAW, yaitu:

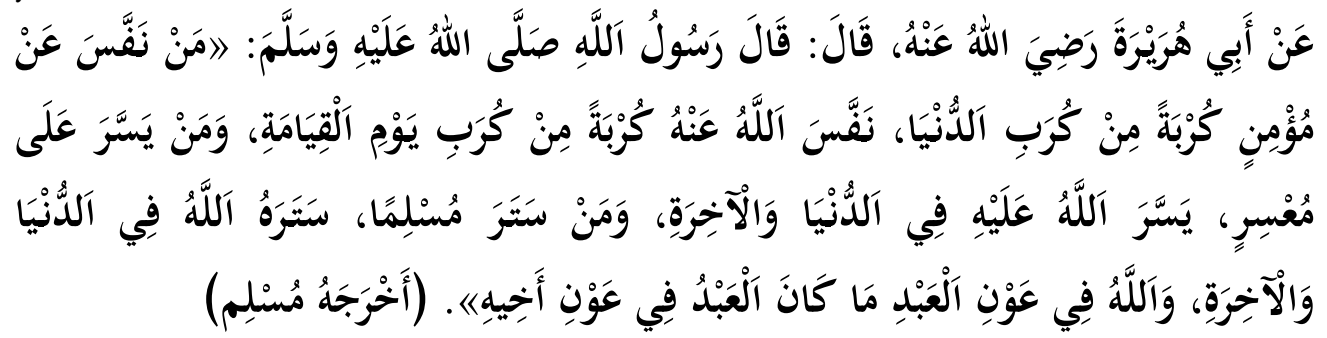

Artinya: Dari Abū Hurairah rađìaLlāhu 'anbu, ia berkata; Rasulullah şallaLläbu 'alaibi wasallam telah bersabda: Barang siapa membebaskan seorang mukmin dari suatu kesulitan dunia, maka Allab akan membebaskannya dari suatu kesulitan pada hari kiamat. Barang siapa memberi kemudahan kepada orang yang berada dalam kesulitan, maka Allah akan memberikan kemudahan di dunia dan akbirat. Barang siapa menutupi aib seorang muslim, maka Allab

\footnotetext{
${ }^{4}$ William Chang, Pengantar Teologi Moral, (Jakarta: 2001), h. 48.

${ }^{5}$ ibid
} 
akan menutup aibnya di dunia dan akbirat. Allah akan selalu menolong hambaNya selama hamba tersebut menolong saudaranya sesama muslim. ${ }^{6}$

Di dalam al-Qur'an sendiri Allah SW'T tidak pernah memisahkan antara ibadah dan melakukan perbuatan sosial, seperti ungkapan "Aqimu al-Shalat wa atu al-zakat" artinya dirikanlah shalat dan tunaikanlah zakat, maknanya adalah ibadah selalu dibaringi dengan kepedulian sosial. Muslim yang baik tidak hanya melakukan ibadah shalat saja akan tetapi ia juga peduli terhadap lingkungan sosialnya, dengan membantu orang miskin, membantu kesusahakan orang lain, dan lain sebagainya.

Apabila seluruh anggota masyarakat memiliki tingkat kesadaran sosial yang tinggi maka kehidupan masyarakat yang harmonis akan terwujud. Kenyataan yang sekarang kita jumpai dalam kehidupan sehari-hari, ${ }^{7}$ tingkat kesadaran sosial di masyarakat mengalami pemudaran (perlahan sirna).

Tentunya masih banyak lagi kasus penyimpangan sosial yang ada di masyarakat, karena kesadaran sosial yang telah hilang maka setiap anggota masyarakat memiliki kecenderungan untuk berbuat sekehendak hatinya, tanpa lagi mempedulikan kaidah sosial yang berlaku. Dalam kurun waktu berikutnya, apabila kesadaran sosial ini semakin sirna maka dapat mengakibatkan perubahan yang besar dimasyarakat. Perubahan sosial tersebut antara lain norma/kaidah/nilai/pranata "dianggap tidak ada, dianggap tidak perlu, dianggap tidak penting". Bila hal ini yang terjadi di masyarakat dapat dipastikan bahwa kehidupan masyarakat akan seperti kehidupan di hutan, falsafah yang kuat akan berkuasa, yang pandai akan menguasai yang bodoh, yang kuat akan menguasai yang lemah. Tidak akan ada lagi demokrasi di masyarakat.

Ketentraman hidup yang didambakan akan sirna. Dengan uraian singkat tersebut maka kesadaran sosial sangatlah penting untuk menciptakan keserasian/ keharmonisan/ keseimbangan sosial. Oleh karena itu, seluruh anggota masyarakat, camat, polisi, guru, siswa dan warga masyarakat di tuntut untuk meningkatkan kesadaran sosial.

${ }^{6}$ Imam Muslim, Shahih Muslim, (Keiro: Dar el-Fikri, tt), hadis no. 4867

7 Banyak kasus yang dapat kita jumpai, misalnya: 1) Maraknya korupsi yang dilakukan oleh pejabat Negara; 2) Kekerasan dalam rumah tangga; 3) Aksi guru yang membanting muridnya; 4) Perkelahian antar pelajar; 5) Makin merebaknya free sex dikalangan pelajar; 6) Aksi mesum aparat pemerintah; 7) Main hakim sendiri warga masyarakat; 8) Seorang hakim yang mau disuap; 9) Aksi pembunuhan yang sadis; 10) Pengrusakan balai desa oleh warga; 11) Maraknya perjudian/togel ada di mana-mana; 12) Maraknya prostitusi di masyarakat; 13) Makin banyaknya kasus penyalahgunaan narkoba di masyarakat; 14) Makin beragamnya penipuan di masyarakat; 15) Pembuangan sampah sembarangan; dan lain-lain. Lihat Lidia Nauli, Kesadaran Sosial Membentuk Solidaritas Sosial, Jurnal. Undip. 2015. 
Bentuk kesadaran sosial yang digunakan seseorang dapat dipengaruhi oleh tiga hal, yaitu kognisi, tujuan, dan motif. Setiap individu memiliki kebiasaan atau gaya tersendiri dalam memperhatikan informasi yang didapat dari lingkungan sosialnya. Hal ini menunjukkan bahwa sistem kognitif yang dimiliki individu berbeda satu sama lain dan dapat mempengaruhi kesadaran sosial mereka dalam berinteraksi sosial. Selain dari sistem kognisi, kesadaran sosial dapat dipengaruhi oleh tujuan dan motif. Tujuan dan motif tersebut merefleksikan informasi sosial yang dibutuhkan oleh seseorang. Contohnya, orang yang seringkali memposisikan dirinya sebagai orang lain demi mengerti apa yang dirasakan oleh orang lain akan memiliki kecendrungan melakukan hal tersebut karena kebutuhan yang tinggi akan keakraban atau keintiman. Sebagai tambahan, berdasarkan hal-hal yang mempengaruhi kesadaran sosial, kesadaran lingkungan sosial dapat membantu seseorang untuk mengumpulkan informasi sosial yang dibutuhkan dalam membangun jembatan antara diri sendiri dan orang lain dalam kehidupan bermasyarakat.

Untuk menumbuhkan kesadaran sosial maka bisa dimulai di lingkungan sekolah, baik atau tidaknya sosial dari seorang siswa tergantung dari manajemen kepala sekolah. Kepala sekolah sangat berperan penting di dalam menumbuhkan kesadaran sosial bagi siswanya, dan ini bisa terwujud dengan menggunakan cara dan manajemen yang dibuat oleh kepala sekolah.

Manajemen sebagai salah satu kepemimpinan sangat penting untuk mencapai suatu tujuan organisasi. Dengan sangat berat seolah-olah kepemimpinan dipaksa mengahadapi berbagai macam faktor seperti: struktur atau tatanan, kondisi lingkungan organisasi, dan kekuasaan. Maju dan mundurnya suatu organisasi sangat berpengaruh pada pemimpinnya.

Sekolah adalah lembaga bersifat kompleks dan unik. Bersifat kompleks karena sekolah sebagai organisasi didalamnya terdapat berbagai dimensi yang saling berkaitan. Dan sifat unik, menunjukkan bahwa sekolah sebagai organisasimemiliki cirri-ciri tertentu yang tidak dimiliki organisasi-organisasi lain. Sekolah memiliki karakter tersendiri, di mana terjadi proses belajar mengajar, tempat terselenggaraannya pembudayaan kehidupan umat manusia. Sekolah sebagai organisasi memerlukan tingkat koordinasi yang tinggi. Keberhasilan sekolah adalah keberhasilan kepala sekolah.

Kepala sekolah yang berhasil apabila mereka memahami keberadaan sekolah sebagai organisasi, serta mampu melaksanakan peranan kepala sekolah sebagai seseong yang diberi tanggung jawab untuk memimpin sekolah. Kepala sekolah dilukiskan sebagai orang yang memiliki harapan tinggi bagi para staf dan para siswa, kepala sekolah harus mengetahui tugas-tugas nya, dan para kepala sekolah yang menentukan bagi sekolahnya. Betapa penting peranan kepala sekolah dalam menggerakkan kehidupan sekolah mencapai tujuan. Kepala sekolah berperan sebagai kekuatan sentral yang menjadi kekuatan penggerak 
kehidupan sekolah dan kepala sekolah harus memahami tugas dan fungsi mereka demi keberhasilan sekolah, serta memiliki kepedulian kepada staf dan siswa. $^{8}$

Kepemimpinan pendidikan ini berkaitan dengan masalah kepala sekolah dalam meningkatkan kesempatan untuk mengadakan pertemuan secara efektif dengan para guru dalam situasi yang kondusif. Dalam hal ini, perilaku kepala sekolah harus dapat mendorong kinerja para guru dengan menunjukkan rasa bersahabat, dekat dan penuh pertimbangan terhadap para guru, baik sebagai individu maupun sebagai kelompok. Perilaku instrumental kepala sekolah merupakan tugas-tugas yang diorientasikan dan secara langsung diklarifikasi dalam peranan dan tugas-tugas para guru, sebagai individu dan sebagai kelompok. Perilaku kepala sekolah yang positif dapat mendorong, mengarahkan dan memotivasi seluruh warga sekolah untuk bekerja sama daam mewujudkan visi, misi dan tujuan sekolah.

Kinerja kepemimpinan kepala sekolah merupakan upaya yang dilakukan dan hasil yang dapat dicapai oleh kepala sekolah dalam mengimplementasikan manajemen sekolah untuk mewujudkan tujuan pendidikan secara efektif dam efisien, produktif dan akuntabel. Oleh karena itu, kepala sekolah memiliki posisi yang sangat penting dalam menggerakkan manajemen sekolah agar dapat berjalan sesuai dengan tuntutan masyarakat dan perkembangan kebutuhan zaman; khususnya kemajuan ilmu pengetahuan, teknologi, budaya dan seni. Pentingnya kepemimpinan kepala sekolah ini perlu lebih ditekankan lagi, terutama dalam kaitanya dengan kebijakan otonomi daerah dan desentralisasi pendidikan. Dalam desentralisasi pendidikan yang menekankan pada manajemen berbasis sekolah, kepala sekolah memiliki otonomi yang tinggi dalam memajukan dan mengembangkan sekolahnya.

Pendidikan sesungguhnya memiliki peranan yang sangat penting dalam upaya meningkatkan kualitas suatu bangsa. Peningkatan taraf hidup, status sosial dan martabat manusia dapat dilakukan melalui jalur pendidikan. Hal ini sangat mungkin karena salah satu fungsi pendidikan adalah proses memanusiakan manusia dalam rangka mewujudkan budayanya. Ishomuddin menyatakan bahwa manusia diciptakan dalam keadaan fitrah. Fitrah dalam al-Qur'an pada dasarnya memiliki arti kesiapan manusia untuk menerima kondisi yang ada di sekelilingnya dan mampu menghadapi tantangan serta dapat mempertahankan dirinya untuk survive dan berkembang selaras dengan al-Qur'an dan al-Sunnah. ${ }^{10}$

${ }^{8}$ Wahjosumidjo, Kepemimpinan Kepala Sekolah, (Jakarta: RajaGrafindo, 1995), hal. 83 .

${ }^{9}$ Mulyasa, Manajemen dan Kepemimpinan Kepala Sekolah, (Jakarta: Bumi Aksara, 2011), hal.17.

${ }^{10}$ Ishomuddin, Pendidikan Karakter, (Jakarta: 1996), h. 11. 
Secara spesifik, pendidikan Islam mengharuskan terjadinya proses internalisasi nilai ketuhanan pada diri manusia secara bertahap sesuai tugas perkembangannya. Pada tujuan inilah semestinya akan terbentuk kepribadian manusia yang utuh secara lahir dan batin, yang menampakkan corak wataknya dalam amal perbuatan dan tingkah laku. Ini adalah salah satu pola kehidupan ideal yang hendak dibentuk melalui proses pendidikan yang Islami.

Sekolah ${ }^{11}$ berasal dari bahasa belanda school, bahasa jerman die scrule, yang artinya sekolah, yaitu suatu lembaga pendidikan. ${ }^{12}$ Jadi sekolah dapat di artikan sebuah lembaga pendidikan formal sebagai tempat belajar siswa atau disebut gedung tempat belajar. Sekolah merupakan lembaga pendidikan yang penting, pada zaman dulu dan terlebih lagi pada zaman sekarang ini. Dewasa ini sekolah merupakan kebutuhan setiap orang untuk mendapatkan pendidikan dari sekolah. Sekolah mempunyai dua aspek penting yaitu aspek individu dan aspek sosial. Disatu pihak, pendidikan sekolah bertugas mempengaruhi dan menciptakan kondisi yang memungkinkan perkembangan secara optimal. Sekolah sebagai pendidikan formal dituntut untuk dapat merekam segala fenomena yang terjadi di masyarakat. Selanjutnya sekolah memberikan informasi dan penjelasan kepada peserta didik terhadap ontologis suatu peristiwa. ${ }^{13}$

Di dalam kehidupan sehari - hari tentunya manusia tidak dapat lepas dari hubungan antara satu dengan yang lainnya, ia akan selalu perlu untuk mencari individu ataupun kelompok lain untuk dapat berinteraksi ataupun bertukar pikiran. Apalagi didalam lingkungan sekolah, interaksi sangat banyak dilkukan, baik antara siswa dengan siswa, guru dengan guru, maupun siswa dengan guru.

Menurut Prof. Dr. Soerjono Soekamto di dalam pengantar sosiologi, interaksi sosial merupakan kunci semua kehidupan sosial. Dengan tidak adanya komunikasi ataupun interaksi antar satu sama lain maka tidak mungkin ada kehidupan bersama. Jika hanya fisik yang saling berhadapan antara satu sama lain, tidak dapat menghasilkan suatu bentuk kelompok sosial yang dapat saling berinteraksi. Maka dari itu dapat disebutkan bahwa interaksi merupakan dasar dari suatu bentuk proses sosial karena tanpa adanya interaksi sosial, maka kegiatan-kegiatan antar satu individu dengan yang lain tidak dapat disebut interaksi.

Fungsi edukatif formal yang diemban oleh sekolah terutama berlangsung dalam kelas. Disini berlangsung interaksi antara guru dengan pelajar yang secara formal diprogramkan dan dilaksanakan paling intensif. Selain interaksi antara

${ }^{11}$ Sekolah adalah sebuah lembaga yang di rancang untuk pengajaran siswa di bawah pengawasan pendidik dalam upaya menciptakan anak didik agar dapat mengalami kemajuan setelah melalui pembelajaran.

${ }^{12}$ Moh. Padil, Sosiologi Pendidikan, (Yogyakarta: UIN-Maliki Press, 2007), hal. 145

${ }^{13}$ Damser, Pengantar Sosiologi Pendidikan,( Jakarta : Kencana, 2008) 
guru dengan pelajar, dalam kelas juga terjadi interaksi antar pelajar. Kedua macam hasil interaksi dalam kelas ini berpengaruh besar terhadap prestasi belajar itulah sebabnya interaksi ini akan mendapat perhatian-perhatian khusus.

Interaksi atau saling berhubungan dan saling mempengaruhi antar warga suatu kelompok, dalam hal ini kelas melahirkan apa yang biasa dinamakan iklim atau suasana kelas. Interaksi antar individu dalam kelas ini dilandasi oleh peraturan-peraturan yang berlaku untuk sekolah secara keseluruhan. Akan tetapi peraturan-peraturan mekandasi interaksi itu sama untuk setiap kelas dalam suatu sekolah, diantara kelas-kelas terdapat perbedaan suasana yang kadang-kadang cukup jelas. Ini berarti bahwa interaksi merupakan factor dominan bagi suasana kelas.

Dengan demikian, baik secara mikro maupun makro posisi pendidikan Islam menduduki tempat yang sangat strategis dalam membentuk kepribadian individu yang pada akhirnya akan memberi warna pada karakter suatu bangsa.

\section{Kepala Madrasah}

Faktor terpenting dalam kegiatan menggerakkan orang lain untuk menjalankan administrasi atau manajemen adalah kepemimpinan (leadership). Mengapa demikian? Sebab, kepemimpinanlah yang menentukan arah dan tujuan, memberikan bimbingan dan menciptakan iklim kerja yang mendukung pelaksanaan proses administrasi secara keseluruhan. Kesalahan dalam kepemimpinan dapat mengakibtakan gagalnya lembaga dalam menjalankan misinya. ${ }^{14}$

Sebagai pemimpin di lingkungannya, kepala sekolah tidak hanya wajib melaksanakan tugas-tugas administratif tapi juga menyangkut tugas-tugas bagaimana harus mengatur seluruh program sekolah. Dia harus mampu memimpin dan mengarahkan aspek-aspek baik administratif maupun proses kependidikan di sekolahnya, sehingga sekolah yang dipimpinnya menjadi dinamis dan dialektis dalam usaha inovasi. Peranan kepemimpinannya di sekolah harus digerakkan sedemikian rupa sehingga pengaruhnya dapat dirasakan di kalangan staf dan guru-guru langsung atau tidak langsung. Oleh karenanya, perilakunya sebagai orang yang memegang kunci dalam perbaikan administrasi dan pengajaran harus mampu menggerakkan kegiatan-kegiatan dalam rangka inovasi di bidang metode pengakaran, teknik mengajar, dalam mencobakan ide-

${ }^{14}$ Burhanuddin, Analisis Administrasi Manajemen dan Kepemimpinan Pendidikan, cet. I., (Jakarta: Bumi Aksara, 1994), hal. 61. 
ide baru dan mencobakan praktek baru, serta dalam bentuk manajemen kelas yang lebih efektif dan sebagainya. ${ }^{15}$

Lebih-lebih di era globalisasi ini, kemenangan ditentukan oleh mutu SDM. Mutu SDM itu sendiri ditentukan oleh pendidikan bermutu baik pada tingkat dasar, menengah maupun tinggi. Pendidikan memegang peranan kunci dalam usaha mencerdaskan kehidupan bangsa. Hal ini sesuai dengan cita-cita dan sumpah dari founding fathers kita untuk membangun suatu masyarakat Indonesia yang kuat, demokratis, mandiri, menghayati nilai-nilai untuk bersatu dalam kebhinekaan, menguasai ilmu dan teknologi, dan mampu bersaing dalam era kehidupan domestik dan global.

Bertitik dari hal ini, sebagai pemimpin tunggal di sekolah, seorang kepala sekolah dituntut memiliki tanggung jawab untuk mengajar dan mempengaruhi semua yang terlibat dalam kegiatan pendidikan di sekolah, untuk bekerjasama dalam mencapai tujuan sekolah.

Ukuran keberhasilan kepala sekolah dalam menjalankan tugasnya, adalah dengan mengukur kemampuannya di dalam menciptakan "iklim belajar mengajar", dengan mempengaruhi, mengajak, dan mendorong guru, siswa dan staf lainnya untuk menjalankan tugasnya masing-masing dengan sebaik-baiknya. Terciptanya iklim belajar mengajar secara tertib, lancar dan efektif ini tidak terlepas dari kegiatan pengelolaan yang dilakukan oleh kepala sekolah dalam kapasitasnya sebagai administrator (baca: supervisor) dan pemimpin pendidikan di sekolah. ${ }^{16}$

Hal ini, dilakukan dalam rangka untuk menciptakan iklim yang kondusif di sekolah, sehingga akan terwujud suatu perubahan dan pengembangan yang akhirnya akan mampu menghasilkan sekolah yang efektif dan produktif. Namun, harus diingat, bahwa upaya ini tidak akan berhasil dan tepat sasaran jika tidak ditunjang dengan pemahaman dan penerapan prinsip-prinsip peningkatan mutu, seperti; keterpaduan, sistem strategis untuk memenuhi kepuasan stakeholders (peran serta masyarakat dalam pendidikan), melibatkan administrator (supervisor) serta unsur-unsur sekolah lainnya dalam upaya peningkatan mutu secara berkelanjutan.

Kepala sekolah merupakan administrator pendidikan yang bertanggung jawab terhadap kelancaran pelaksanaan pendidikan dan pengajaran di sekolahnya. Oleh karenanya, untuk dapat melaksanakan tugasnya dengan baik,

${ }^{15}$ M. Arifin, Kapita Selekta Pendidikan (Islam dan Umum), cet. III., (Bandung: Bumi Aksara, 1995), hal. 155.

${ }^{16}$ Nanang Fattah, Konsep Manajemen Berbasis Sekolah (MBS) dan Dewan Sekolah, cet. I., (Bandung: Pustaka Bani Quraisy, 2004), hal. 125-126. 
kepala sekolah hendaknya memahami, menguasai, dan mampu melaksanakan kegiatan-kegiatan yang berkenaan dengan fungsinya sebagai administrator pendidikan. ${ }^{17}$

Kegiatan administrator pendidikan tersebut yang mana di dalamnya terkandung fungsi-fungsi perencanaan, pengorganisasian, pengkoordinasian, pengawasan, kepegawaian, dan pembiayaan. Dengan demikian, kepala sekolah sebagai adminstrator dituntut untuk mampu mengaplikasikan fungsi-fungsi tersebut ke dalam pengelolaan sekolah yang dipimpinnya.

a. Membuat perencanaan

Salah satu fungsi utama dan pertama yang menjadi tanggung jawab kepala sekolah adalah membuat atau menyusun perencanaan. Perencanaan merupakan salah satu syarat mutlak bagi setiap organisasi atau lembaga dan bagi setiap kegiatan, baik perorangan dan atau kelompok. Tanpa perencanaan atau planning, pelaksanaan suatu kegiatan akan mengalami kesulitan dan bahkan mungkin juga kegagalan.

Oleh karena itu, setiap kepala sekolah paling tidak harus membuat rencana tahunan. Setiap tahun, menjelang dimulainya tahun ajaran baru, kepala sekolah hendaknya sudah siap menyusun rencana yang akan dilaksanakan untuk tahun ajaran berikutnya. Sesuai dengan ruang lingkup administrasi sekolah, maka rencana atau program tahunan hendaklah mencakup bidang-bidang, seperti; a) program pengajaran, seperti kebutuhan tenaga guru sehubungan kepindahan dan lain-lain, pembagian tugas mengajar, pengadaan buku-buku pelajaran, alat-alat pelajaran, dan alat peraga, pengadaan dan pengembangan laboratorium sekolah, pengadaan atau pengembangan perpustakaan sekolah, sistem penilaian hasil belajar, kegiatan kokurikuler, dan lain-lain, b) kesiswaan, seperti syarat-syarat dan prosedur penerimaan siswa baru, pengelompokan siswa dan pembagian kelas, bimbingan atau konseling siswa, pelayanan kesehatan siswa (UKS), dan sebagainya, c) kepegawaian, seperti penerimaan dan penempatan guru atau pegawai baru, pembagian tugas guru dan pegawai sekolah, mutasi dan atau promosi guru dan pegawai sekolah, dan sebagainya, d) keuangan, yang mencakup pengadaan dan pengelolaan keuangan untuk berbagai kegiatan yang telah direncanakan, baik uang yang berasal dari pemerintah, atau dari BP3, atau sumber lainnya, dan e) perlengkeapan, yang meliputi perbaikan atau rehabilitasi gedung sekolah, penambahan ruang kelas, perbaikan atau

${ }^{17}$ M. Ngalim Purwanto, Administrasi dan Supervisi Pendidikan, cet. V., (Bandung: Remaja Rosda Karya, 1992), hal. 106. 
pembuatan pagar pekarangan sekolah, perbaikan atau pembuatan lapangan olah raga, perbaikan atau pengadaan bangku siswa, dan sebagainya. ${ }^{18}$

b. Menyusun organisasi sekolah

Kepala sekolah sebagai administrator pendidikan perlu menyusun organisasi sekolah yang dipimpinnya, dan melaksanakan pembagian tugas serta wewenangnya kepada guru-guru dan pegawai sekolah sesuai dengan struktur organisasi sekolah yang telah disusun dan disepakati bersama.

Untuk menyusun organisasi sekolah yang baik perlu diperhatikan prinsip-prinsip sebagai berikut:

1) Mempunyai tujuan yang jelas,

2) Para anggota menerima dan memahami tujuan tersebut,

3) Adanya kesatuan arah sehingga dapat menimbulkan kesatuan tindakan, kesatuan pikiran, dan sebagainya,

4) Adanya kesatuan perintah (unity of command), para bawahan/anggota hanya mempunyai seorang atasan langsung, dan daripadanya ia menerima perintah atau bimbingan, serta kepadanya ia harus mempertanggungjawabkan pekerjaannya,

5) Adanya keseimbangan antara wewenang dan tanggung jawab seseorang di dalam organisasi tersebut. Sebab, tidak adanya keseimbangan tersebut akan memudahkan timbulnya hal-hal yang tidak diinginkan, seperti: a) jika wewenang lebih besar daripada tanggung jawab, mudah menimbulkan penyalahgunaan wewenang, b) jika tanggung jawab lebih besar daripada wewenang, mudah menimbulkan banyak kemacetan, merasa tidak aman atau ragu-ragu dalam tindakan.

6) Adanya pembagian tugas pekerjaan yang sesuai dengan kemampuan, keahlian, dan atau bakat masing-masing.

7) Struktur organisasi hendaknya disusun sesederhana mungkin, sesuai dengan kebutuhan koordinasi, pengawasan, dan pengendalian.

8) Pola organisasi hendaknya relatif permanen. Artinya, meskipun struktur organisasi dapat dan memang harus diubah sesuai dengan tuntutan perkembangan, fleksibilitas dalam penyesuaian itu jangan bersifat prinsip. Oleh karena itu, pola dasar struktur organisasi perlu dibuat sedemikian rupa sehingga sedapat mungkin permanen.

9) Adanya jaminan keamanan dalam bekerja (security of tunere), bawahan atau anggota tidak merasa gelisah karena takut dipecat, ditindak sewenangwenang dan sebagainya,

10) Garis-garis kekuasaan dan tanggung jawab serta hierarki tata kerjanya jelas tergambar di dalam struktur atau bagan organisasi. ${ }^{19}$

${ }^{18}$ Ibid., hal, 106-107. 
c. Bertindak sebagai koordinator dan pengarah

Adanya koordinasi serta pengarahan yang baik dan berkelanjutan dapat menghindarkan kemungkinan terjadinya persaingan yang tidak sehat anatarbagian atau antarpersonal sekolah, dan atau kesimpangsiuran dalam tindakan. Dengan kata lain, adanya pengkoordinasian yang baik memungkinkan semua bagian atau personal bekerjasama saling membantu ke arah satu tujuan yang telah ditetapkan seperti kerjasama antara urusan kurikulum dan pengajaran dengan guru-guru, bimbingan dan konseling dengan para wali kelas, TU dengan wali kelas dan guru-guru, kerjasama antara BP3 dengan bagian bimbingan dan konseling dan para wali kelas, dan sebagainya.

d. Melaksanakan pengelolaan kepegawaian

Tugas-tugas yang menyangkut pengelolaan kepagawaian ini sebagaian besar dikerjakan oleh bagian TU sekolah seperti pengusulan guru dan atau pegawai baru, kenaikan pangkat guru, pegawai sekolah, dan sebagainya.

Hal yang termasuk kegiatan pengelolaan kepagawaian ialah masalah kesejahteraan personel. Yang dimaksud kesejahteraan personel bukan sekedar kesejahteraan yang berupa materi atau uang, akan tetapi juga kesejahteraan yang bersifat rohani dan jasmani, yang dapat mendorong para pesonel sekolah bekerja lebih giat dan bergairah. Banyak cara dan usaha yang dapat dilakukan kepala sekolah dalam rangka meningkatkan kesejahteraan personel sekolah. Di samping pemberian insentif dan atau gaji yang layak, usaha meningkatkan kesejahteraan personel dapat pula dilakukan dengan usaha-usaha lain. $^{20}$

Selain harus menjalankan fungsi perencanaan, pengorganisasian, pengkoordinasian, pengawasan, kepegawaian, dan pembiayaan tersebut, kepala sekolah dalam menjalankan tugasnya sebagai supervisor juga harus bertolak pada

${ }^{19}$ Ibid., hal. 108-109.

${ }^{20}$ Usaha-usaha lain ini bisa berupa; a) Membentuk semacam ikatan keluarga sekolah yang bersifat sosial, b) Membentuk koperasi keluarga personel sekolah, c) Mengadakan kegiatan-kegiatan seperti olah raga, diskusi-diskusi yang berhubungan dengan pengembangan profesi guru-guru atau pegawai sekolah, d) Memberikan kesempatan dan bantuan dalam rangka pengembvangan karier, seperti kesempatan melanjutkan pendidikan, kesempatan mengikuti pelatihan-pelatihan, selama tidak mengganggu atau merugikan jalannya sekolah, dan e) Mengusulkan dan menguruskan kenaikan gaji atau pangkat guru-guru dan pegawai tepat pada waktunya sesuai dengan peraturan yang berlaku. 
beberapa prinsip, seperti yang diungkapkan oleh Rifa'i yang dikutip oleh M. Ngalim Purwanto, ${ }^{21}$ yaitu:

a. Hendaknya bersifat konstruktif dan kreatif, yaitu pada yang dibimbing dan diawasi harus dapat menimbulkan dorongan untuk bekerja,

b. Harus berdasarkan atas keadaan dan kenyataan yang sebenarnya (realistis, mudah dilaksanakan),

c. Harus sederhana dan informal dalam pelaksanaannya,

d. Harus dapat memberikan perasaan aman dan pada guru-guru dan pegawai-pegawai sekolah yang disupervisi,

e. Harus didasarkan atas dasar profesional, bukan atas dasar hubungan pribadi,

f. Harus selalu memperhitungkan kesanggupan, sikap, dan mungkin prasangka-prasangka guru dan pegawai sekolah,

g. Tidak bersifat mendesak (otoriter) karena dapat menimbulkan perasaan gelisah atau bahkan antipati dari guru-guru,

h. Tidak boleh didasarkan atas kekuasaan pangkat, atau kedudukan pribadi,

i. Tidak boleh mencari-cari kesalahan dan kekurangan,

j. Tidak boleh terlalu cepat mengharapkan hasil, dan tidak boleh lekas merasa kecewa, dan

k. Hendaknya bersifat preventif, ${ }^{22}$ korektif, $^{23}$ dan kooperatif. ${ }^{24}$

Di samping itu, dalam melaksanakan tugas (baca: usaha) secara umum, kepala sekolah harus berorientasi ke arah "membangun" kepada orang yang dipimpinnya, misalnya, antara lain:

a. Membangkitkan dan merangsang guru-guru dan pegawai sekolah di dalam menjalankan tugasnya masing-masing dengan sebaik-baiknya,

b. Berusaha mengadakan dan melengkapi alat-alat perlengakapan sekolah termasuk media instruksional yang diperlukan bagi kelancaran dan keberhasilan proses belajar mengajar,

c. Bersama guru-guru berusaha mengembangkan, mencari, dan menggunakan metode-metode mengajar yang lebih sesuai dengan tuntutan kurikulum yang sedang berlaku,

21 M. Ngalim Purwanto, Op.Cit., hal. 117.

${ }^{22}$ Preventif berarti berusaha mencegah jangan sampai timbul hal-hal yang negatif, mengusahakan atau memenuhi syarat-syarat sebelum terjadinya sesuatu yang tidak diharapkan.

${ }^{23}$ Korektif berarti memperbaiki kesalahan-kesalahan yang telah diperbuat.

24 Kooperatif berarti bahwa mencari kesalahan-kesalahan atau kekurangankekurangan dan usaha memperbaikinya dilakukan bersama-sama oleh supervisor dan orang-orang yang diawasi. 
d. Membina kerjasama yang baik dan harmonis di antara guru-guru dan pegawai sekolah lainnya,

e. Berusaha mempertinggi mutu dan pengetahuan guru-guru dan pegawai sekolah, antara lain dengan mengadakan diskusi-diskusi kelompok, menyediakan perpustakaan sekolah, dan atau menegirim mereka untuk mengikuti pelatihan, seminar, sesuai dengan bidangnya masing-masing, dan

f. Membina hubungan kerja sama antara sekolah dengan BP3 dan instansiinstansi lain dalam rangka peningkatan mutu pendidikan para siswa.

Sedangkan secara khusus dan lebih kongkrit lagi, usaha-usaha yang mungkin dapat dilakukan oleh kepala sekolah sebagai supervisor dapat dirumuskan sebagai berikut:

a. Menghadiri rapat atau pertemuan organisasi-organisasi profesional, seperti PGRI, dan sebagainya,

b. Mendiskusikan tujuan-tujuan dan filsafat pendidikan dengan guru-guru,

c. Mendiskusikan metode dan teknik-teknik dalam rangka pembinaan dan pengembangan proses belajar mengajar,

d. Membimbing guru-guru dalam penyusunan Program Semester dan Program Satuan Pelajaran,

e. Membimbing guru-guru dalam memilih dan menilai buku-buku untuk perpustakaan sekolah dan buku-buku pelajaran bagi siswa,

f. Membimbing guru-guru dalam menganalisis dan menginterpretasikan hasil tes dan penggunaannya bagi perbaikan proses belajar mengajar,

g. Melakukan kunjungan kelas atau classroom visitation dalam rangka sipervisi klinis,

h. Mengadakan kunjungan obeservasi atau observation visit bagi guru-guru demi perbaikan cara mengajarnya,

i. Mengadakan peretemuan-pertemuan individu dengan guru-guru tentang masalah-masalah yang mereka hadapi atau kesulitan-kesulitan yang mereka alami,

j. Menyelenggarakan manual atau buletin tentang pendidikan dalam ruang lingkup bidang tugasnya, dan

k. Berwawancara dengan orang tua siswa dan pengurus BP3 tentang hal-hal yang mengenai pendidikan anak-anak mereka. ${ }^{25}$

Jika item-item yang tersebut di atas dapat dijalankan dengan baik oleh semua komponen sekolah, maka tidak mustahil mutu pendidikan dalam rangka mencapai hasil yang maksimal akan bisa tercapai dan direalisasikan.

${ }^{25}$ M. Ngalim Purwanto, Op.Cit., hal. 119-120. 
Mutu dalam pendidikan mempunyai dimensi yang khas, yang membedakannya dengan dunia industri. Dalam pendidikan, mutu menunjuk pada dua hal, yaitu proses dan produk. Mutu proses pendidikan di lembaga pendidikan dapat diartikan sebagai kemampuan lembaga baik teknis maupun profesional pengelolaan yang mendukung proses belajar siswa agar dapat mencapai prestasi seoptimal mungkin. Sedangkan produk pendidikan termasuk bermutu, jika memenuhi ciri-ciri sebagai berikut; 1) Siswa menunjukkan tingkat penguasaan yang tinggi terhadap tugas belajar sesuai dengan tujuan dan sasaran pendidikan sehingga memiliki pengetahuan dan keterampilan yang diperlukan (kompetensi), 2) Hasil pendidikan sesuai dengan kebutuhan lingkungan khususnya dunia kerja (relevansi), 3) Hasil pendidikan sesuai dengan kebutuhan peserta didik sehingga dapat melakukan sesuatu untuk keperluan hidupnya dalam rangka penyesuaian diri dengan perubahan yang terjadi dalam kehidupan di masyarakat (fleksibilitas), 4) Hasil pendidikan tidak mengakibatkan adanya pemborosan ekonomi maupun pemborosan sosial (efisiensi), 5) Hasil pendidikan dapat menghasilkan sesuatu yang produktif (berdaya hasi), 6) Hasil pendidikan memberikan kepastian/jaminan mutu, 7) Hasil pendidikan dapat dipertanggungjawabkan (kredibilitas dari segi kemampuannya), 8) Hasil pendidikan memberikan sesuatu yang memenuhi spesifikasi dan bernilai tinggi sehingga mengakibatkan justifikasi uang yang dikeluarkan pemakainya, 9) Hasil pendidikan dapat merespon (responsiveness) tuntutan kebutuhan masyarakat, 10) Hasil pendidikan dapat dimanfaatkan dalam jangka waktu yang realtif lama (durability), 11) Hasil pendidikan dapat memberikan sesuatu yang menarik dan berseni (estetik), 12) Hasil pendidikan dapat dilihat dari unjuk kerja (performance) dan etos kerja, dan 14) Hasil pendidikan bebas dari bahaya dan resiko atau keraguan (security). ${ }^{26}$

Menurut Barnett ${ }^{27}$ ada tiga aliran dalam mendekati konsep mutu pendidikan, yaitu aliran obyektivitas, relativitas dan perkembangan. Aliran objektivitas berangkat dari asumsi bahwa dimungkinkan untuk mengidentifikasi dan menghitung aspek-aspek tertentu dari masukan (in put) dan luaran (out $p u t$ ) pendidikan yang menggambarkan mutu pendidikan. Sedangkan aliran relativitas berpandangan bahwa tidak ada kriteria yang absolut yang dapat diterapkan untuk menggambarkan mutu pendidikan secara valid karena pada hakekatnya setiap institusi pendidikan itu berbeda baik tujuan, tradisi, maupun kondisi sosialnya. Sedangkan untuk aliran perkembangan lebih mendekati kualitas pendidikan untuk kepentingan peningkatan mutu kinerja dari lembaga pendidikan. Oleh sebab itu, fokus

${ }^{26}$ Ibid.

${ }^{27}$ Muljani A. Nurhadi, Paradigma Baru Pengelolaan Pendidikan di Daerah Dalam Rangka Desentralisasi Pendidikan, (Yogyakarta: Pustaka Pelajar, 2002), hal. 12. 
pendekatannya adalah kualitas dalam arti aktivitas yang berkaitan dengan proses pendidikan. Maka dari itu, dalam pendekatan terakhir ini yang dievaluasi adalah prosesnya bukan masukan atau luarannya, dengan menggunakan indikator kualitatif bukan kuantitatif.

Kemudian menurut berbagai literatur yang lain menunjukkan bahwa mutu pendidikan dapat dilihat dari berbagai sisi: masukan, proses, luaran, dan bahkan dampaknya ${ }^{28}$, tetapi dalam kenyataan sehari-hari mutu hanya didekati dari segi masukan instrumental dan luarannya saja dan bersifat ekstrinsik. Bahkan mutu luaran hanya ditafsirkan dengan nilai hasil belajar yang bersifat kognitif saja yang tertera pada hasil nilai indek prestasi komulatif akhir. Pendekatan seperti ini mengandung tiga kelemahan.

Pertama, pendekatan mutu pendidikan dari segi masukan instrumental saja ternyata bisa menyesatkan karena berbagai penelitian menunjukkan bahwa bukan masukan instrumental yang menunjang mutu pendidikan, tetapi lebih kepada proses, yaitu bagaimana masukan instrumental itu digunakan dalam proses pendidikan. Begitu pula dengan melihat mutu pendidikan dari luaran yang hanya mengandalkan pengukuran hasil belajar kognitif, sangat menyederhanakan makna mutu pendidikan.

Kedua, mengacu mutu pendidikan dari kacamata luar saja, misalnya pengusaha, instansi pemerintah, dan swasta (stakeholders) sebagai pengguna lulusan, juga tidak memberikan gambaran yang komplit tentang mutu hasil pendidikan, karena justru orang di dalam sekolah, seperti tenaga pendidik, supervisi dan lai-lain. Yang paling tahu bagaimana mutu pendidikan itu berkembang di dalam proses pendidikan.

Ketiga, penelitian terhadap mutu pendidikan secara ekstrinsik, misalnya mengatakan mutu pendidikan rendah karena banyak sarjana yang menganggur, banyak lulusan tidak bisa bekerja dan sebagainya, hanya mampu melihat kulit luarnya saja, bersifat parsial, tidak lengkap dan bias.

Penilaian terhadap mutu pendidikan sebaiknya tidak hanya melihat yang ekstrinsik tetapi juga yang intrinsik terkandung di dalamnya. Mutu pendidikan harus ditafsirkan lebih luas yaitu didasarkan kepada efektifitas program pendidikan, yaitu seberapa besar pengaruh pendidikan yang diperoleh oleh siswa dalam bentuk perkembangan pengetahuan, sikap, nilai dan tingkah laku.

${ }^{28}$ Ace Suryadi Tilaar, Analisis Kebijakan Pendidikan, Suatu Pengantar, (Banduung: Remaja Rosdakarya, 1993), hal. 159-164. 


\section{Kompetensi Sosial Guru}

1. Defenisi Kompetensi Sosial

Kompetensi sosial adalah karakter, sikap dan perilaku atau kemauan dan kemampuan untuk membangun simpul-simpul kerja sama dengan orang lain yang relative bersifat stabil ketika menghadapi permasalahan di tempat kerja yang terbentuk malalui sinergi atau watak, konsep diri, motivasi internal serta kapasitas pengetahuan sosial. Sementara itu menurut Norman D. Livergood "Social Intelligence : the buman capacity to understand whats happening in the world and respondingto that understanding in a personally and socially effective manner". Menurut Karl Alberch terdapat lima dimensi kecerdasan sosial, yaitu29: ${ }^{30}$

a. Situational Awareness. Kesadaran akan situasi yang dapat membuat orang lain merasa senang dan nyaman.

b. Presence. Yaitu kehadiran yang dapat membuat orang lain merasa senang dan nyaman.

c. Authenticity. Keorisinilan dalam bersikap, dapat menerima keadaan sendiri dan mau menerima keadaan orang lain.

d. Clarity. Yaitu kejelasan dalam berkomunikasi dan memberikan informasi kepada orang lain.

e. Emphaty. Yaitu dapat turut merasakan kondisi orang lain serta penuh perhatian dalam berinteraksi dengan orang lain.

Dalam Undang-undang Sistem Pendidikan Nasional No. 20 tahun 2003 pada Pasal 4 ayat 1, menyatakan "pendidikan diselenggarakn secara demokratis dan berkeadilan Berta tidak diskriminatif dengan menjunjung tinggi hak asasi manusia, nilai keagamaan, nilai kultural, dan kemajemukan bangsa". Pernyataan -ini menunjukkan bahwa pendidikan diselenggarakan secara demokratis dan berkeadilan, tidak dapat diurus dengan paradigma birokratik. Karena jika paradigma birokratik yang dikedepankan, tentu ruang kreatifitasdan invoasi dalam penyelenggaraan pendidikan khususnya pada satuan pendidikan sesuai semangat UU SPN 2003 tersebut tidak akan terpenuhi. Penyelenggaraan pendidikan secara demokratis khususnya dalam memberi layanan belajar kepada peserta didik mengandung dimensi sosial, oleh karena itu dalam melaksanakan tugas sebagai pendidik mengedepankan sentuhan sosial.

Artinya kompetensi sosial terkait dengan kemampuan guru sebagai makhluk sosial dalam berinteraksi dengan orang lain. Sebagai makhluk sosial guru berperilaku santun, mampu berkomunikasi dan

${ }^{30}$ Uhar Suharsaputra, Administrasi Pendidikan, (Bandung : Refika Aditama, 2010), hlm.202-204. 
berinteraksi dengan lingkungan secara efektif dan menarik mempunyai rasa empati terhadap orang lain. Kemampuan guru berkomunikasi dan berinteraksi secara efektif dan menarik dengan peserta didik, sesama pendidik dan tenaga kependidikan, orangtua dan wali peserta didik, masyarakat sekitar sekolah dan sekitar di mana pendidik itu tinggal, dan dengan pihak-pihak berkepentingan dengan sekolah.Kondisi objektif ini menggambarkan bahwa kemampuan sosial guru tampak ketika bergaul dan melakukan interaksi sebagai profesi maupun sebagai masyarakat, dan kemampuan mengimplementasikan dalam kehidupan sehari-hari. ${ }^{31}$

Sentuhan sosial, menunjukkan seorang profesional dalam melaksanakan hares dilandasi nilai-nilai kemanusiaan, dan kesadaran akan dampak lingkungan hidup dari efek pekerjaannya, Berta mempunyai nilai ekonomi bagi kemaslahatan masyarakat secara lugs. Kompetensi sosial menurut Slamet PH terdiri dari:

(1) memahami dan menghargai perbedaan (respek)serta memiliki kemampuan mengelola konflik dan benturan; (2)melaksanakan kerjasama secara harmonis dengan kawan sejawat, kepala sekolah dan wakil kepala sekolah dan pihak-pihak terkait lainnya; (3) membangun kerja tim (teamwork) yang kompak, cerdas, dinamis, dan lincah, (4) melaksanakan komunikasi (oral, tertulis, tergambar) secara efektif dan menyenangkan dengan seluruh warga sekolah, orangtua peserta didik, dengan kesadaran sepenuhnya bahwa masing-masing memiliki pecan dan tanggungjawab terhadap kemajuan pembelajaran; (5) memiliki kemampuan memahami dan menginternalisasikan perubahan lingkungan yang berpengaruh terhadap tugasnya; (6)memiliki kemampauan mendudukkan dirinya dalam sistem nilai yang berlaku di masyarakatsekitarnya; dan (7) melaksanakan prinsipprinsip tata kelola yang baik (misalnya: partisipasi, tranparasi, akutabilitas, penegakan hokum, dan profesionalisme).

Pada kompetensi sosial, masyarakat adalah menyangkut perangkat perilaku yang merupakan dasar bagi pemahaman diri dengan bagian yang tidak terpisahkan dari lingkungan sosial serta tercapainya interaksi sosial secara objektif dan efisien.Ini merupakan penghargaan guru di masyarakat, sehingga mereka mendapatkan kepuasan diri dan menghasilkan kerja yang nyata dan efisien, terutama dalam pendidikan nasional. Kompetensi sosial mencakup perangkat perilaku yang menyangkut: Kemampuan interaktif yaitu kemampuan yang menunjang

\footnotetext{
${ }^{31}$ Ibid.
} 
efektivitas interaksi dengan orang lain seperti keterampilan ekspresi diri, berbicara efektif, memahami pengaruh orang lain terhadap diri sendiri, menafsirkan motif orang lain, mencapai rasa aman bersama orang lain: Ketrampilan memecahkan masalah kehidupan seperti mengatur waktu, uang, kehidupan berkeluarga, memahami nilai kehidupan dan sebagainya. Sedangkan kompetensi spritual yaitu pemahaman, penghayatan dan pengamalan kaidah agama dalam berbagai aspek kehidupan.Dengan demikian indikator kemampuan sosial guru adalah mampu berkomunikasi dan bergaul dengan peserta didik, sesama pendidik dan tenaga kependidikan, orangtua dan wali murid, masyarakat dan lingkungan sekitar, dan mampu mengembangkan jaringan.

Manusia merupakan makhluk sosial (zoos politicos) menurut Aristoteles adalah makhluk yang senantiasa ingin hidup berkelompok.Pendapat senada menyatakan bahwa manusia adalah homo politicos. Manusia dalam hal ini tidak bisa menyelesaikan segala permasalahannya sendiri, dia membutuhkan orang lain baik untuk memenuhi kebutuhannya maupun untuk menjalankan perannya selaku makhluk hidup. Maka, manusia perlu berinteraksi denganyang lain dan senantiasa menjaga hubungan agar tetap berlangsung dalam suasana yang kondusif. Melalui proses, komunikasi dengan lingkungan sekitarnya manusia diharapkan mampu bertahan hidup (survive) bahkan berkembang (growth) sesuai dengan potensi yang dimilikinya. ${ }^{32}$

Guru sebagian dari masyarakat merupakan salah satu pribadi yang mendapatkan perhatian khusus di masyarakat. Peranan dan segala tingkah4aku yang dilakukan guru senantiasa dipantau oleh masyarakat.Oleh karena itu, diperlukan sejumlah kompetensi sosial yang perlu dimiliki guru dalam berinteraksi dengan lingkungan masyarakat di tempat dia tinggal.

Kompetensi sosial dalam kegiatan belajar ini berkaitan erat dengan kemampuan guru dalam berkomunikasi dengan masyarakat di sekitar sekolah dan masyarakat tempat guru tinggal sehingga peranan dan cars guru berkomunikasi di masyarakat diharapkan memiliki karakteristik tersendiri yang sedikit banyak berbeda dengan orang lain yang bukan guru. Misi yang di emban guru adalah mini kemanusiaan.Mengajar dan mendidik adalah tugas memanusiakan manusia. Guru harus mempunyai kompetensi sosial karena guru adalah Penceramah Jaman, lebih tajam lagi di tulis oleh In Soekamo dalam tulisan "Guru dalam mass pembangunan" menyebutkan pentingnya guru dalam mass

${ }^{32}$ Winarno surakhmad, Standar Kompetensi dan Sertifikasi Guru, (Bandung: PT Remaja Rosda Karya,2008), h.182. 
pembangunan adalah menjadi masyarakat. Oleh karena itu, tugas guru adalah tugas pelayanan manusia.

Guru di mata masyarakat pada umumnya dan pars peserta didik merupakan panutan dan anutan yang perlu dicontoh dan merupakan surf teladan dalam kehidupannya sehari-hari. Guru merupakan tokoh dan tipe makhluk yang diberi tugas dan beban membina dan membimbing masyarakat ke arah norms yang berlaku. Guru perlu memiliki kompetensi sosial untuk berhubungan dengan masyarakat dalam rangka menyelenggarakan proses belajar mengajar yang efektif karena dengan dimilikinya kompetensi sosial tersebut, otomatis hubungan sekolah dengan masyarakat akan berjalan dengan lancersehingga jika ada keperluan dengan orangtua peserta didik atau masyarakat tentang masalah peserta didik yang perlu diselesaikan tidak akan sulit menghubunginya. ${ }^{33}$

2. Pentingnya Kompetensi Sosial

Guru dalam menjalani kehidupanya seringkali menjadi tokoh, panutan dan identifikasi bagi para peserta didik, dan lingkungannya. ${ }^{34}$ Abduhzen mengungkapkan bahwa: Imam Al-Ghazali menempatkan profesi guru pada posisi tertinggi dan termulia dalam berbagai tingkat pekerjaan masyarakat. Guru dalam pandangan Al-Ghazali mengemban dua sisi sekaligus, yaitu; tugas keagamaan, ketika guru melakukan kebaikan dengan menyampaikan ilmu pengetahuan kepada manusia sebagai makhluk termulia di muka bumi ini. Sedangkan yang termulia dari tubuh manusia adalah hatinya. Guru bertugas menyempurnakan, membersihkan, mensucikan, dan membawa hati itu mendekati Allah Azza Wa Jalla. Yang kedua yaitu tugas sosiopolitik (ke-khalifahan), dimana guru membangun, memimpin, dan menjadi teladan yang menegakkan keteraturan, kerukunan, dan menjamin keberlangsungan masyarakat, yang keduanya berujung pada pencapaian kebahagiaan di akhirat. Oleh karena itu, guru harus memiliki standar kualitas pribadi tertentu, yang mencangkup tanggung jawab, wibawa, mandiri, dan disiplin. ${ }^{35}$

Berkaitan dengan tanggung jawab, guru harus mengetahui serta memahami nilai, norma moral dan sosial, serta berusaha berperilaku dan berbuat sesuai nilai dan norma tersebut. Guru juga harus bertanggung jawab terhadap segala tindakanya dalam pembelajarn di sekolah, dan dalam kehidupan bermasyarakat.

${ }^{33}$ Ibid.

${ }^{34}$ Uhar Suhasaputra, Op Cit., h. 207.

35 Mulyasa, Standar Kompetensi dan Sertifikasi Guru, (Bandung : Remaja Rosdakarya, 2007), h.174. 
Berkenaan dengan wibawa, guru harus mempunyai kelebihan dalam merealisasikan nilai spiritual, emosional, moral, sosial dan intelektual dalam pribadinya, serta memiliki kelebihan dalam pemahaman ilmu pengetahuan, teknologi dan seni sesuai dengan mata pelajaran yang menjadi tanggung jawabnya.

Guru juga harus mampu mengambil keputusan secara mandiri (independent), terutama dalam berbagai hal yang berkaitan dengan pembelajaran dan pembentukan kompetensi, serta bertindak sesuai dengan kondisi peserta didik, dan lingkungan. Guru harus mampu bertindak dan mengambil keputusan secara cepat, tepat waktu dan sasaran, terutama yang berkaitan dengan masalah pembelajaran dan peserta didik, tidak menunggu perintah atasan atau kepala sekolah.

Sedangkan disiplin, dimaksudkan bahwa guru harus mematuhi berbagai peraturan dan tata tertib secara konsisten, atas kesadaran profesional, karena mereka bertugas untuk mendisiplingkan peserta didik di sekolah, terutama dalam pembelajaran. Oleh karena itu, dalam menamkan disiplin guru harus memulai dari dirinya sendiri, dalam berbagai tindakan dan perilakunya.Disinilah pentingnya kompetensi personal atau pribadi guru.

Sebagai individu yang berkecimpung dalam pendidikan, guru harus memliki kepribadaian yang mencerminkan seorang pendidik. Tuntutan akan kepribadian sebagai seorang pendidik kadang-kadang di rasakan lebih berat di banding profesi lainya. Ungkapan yang sering di kemukakan adalah bahwa : "guru bias digugu dan di tiru". Digugu maksudnya bahwa pesan-pesan yang di sampaikan guru bias di percaya untuk di laksanakan dan pola hidupnya bias ditiru atau di teladani.

Guru sering dijadikan panutan oleh masyarakat, untuk itu guru harus mengenal nilai-nilai yang di anut dan berkembang di masyarakat tenpat ia melaksanakan tugas dan tempat tinggalnya. Secara nasional, nilai-nilai tersebut sudah di rumuskan, tetapai barang kali masih ada nilai-nilai yang belum terwadahi dan harus di kenal oleh guru, agar dapat melestarikanya dan berniat untuk tidak berperilaku yang bertentangan dengan nilai tersebut. Jika ada nilai yang bertentangan dengan nilai yang di anutnya, maka dengancara yang tepat ia mengyikapi hal tersebut, sehingga tidak terjadi benturan nilai antara guru dan masyarakat yang berakibat terganggunya proses pendidikan bagi peserta didik. Untuk kepentingan tersebut, wawasan nasional mutlak di perluakan dalam pendidikan dan pembelajaran. ${ }^{36}$

3. Peran Guru di Masyarakat

${ }^{36}$ Ibid., h. 175 
Guru merupakan kunci penting dalam kegiatan hubungan sekolah dengan masyarakat.Oleh karena itu dia harus memilikikompetensi untuk melakukan beberapa hal sebagai berikut.

a. Membantu sekolah dalam melaksanakan teknik-teknik Husemas. Meskipun kepala sekolah merupakan orang kunci dalam pengelolaan Husemas, akan tetapi kepala sekolah tidak mungkin melaksanakan program Husemas tanpa bantuan guru-guru. Guru-guru dapat ditugasi kepala sekolah melaksanakan hal-hal yang berkaitan dengan Husemas, disesuaikan dengan jenis dan bentuk kegiatan yang ada. Sebagai contoh, apabila kepala sekolah ingin melaksanakan kunjungan ke rumah siswa, maka kepala sekolah dapat mendelegasikan tugas kepada guru. Guru-guru juga dapat ditugasi kepala sekolah untuk membuat program kerja yang mempunyai dampak terhadap popularitas sekolah.

b. Membuat dirinya lebih baik lagi dalam bernasyarakat.Guru adalah tokoh milik masyarakat. Tingkah laku atau seoak terjang yang dilakukan guru di sekolah dan di masyarakat menjadi sesuatu yang sangat penting. Apa yang dilakukan atau tidak dilakukan guru menjadi panutan masyarakat. Dalam posisi yang demikian inilah guru harus memperlihatkan perilaku yang prima. Apabila msyarakat telah mengetahui bahwa guru-guru sekolah tertentu dapat dijadikan suri teladan di masyarakat, kepercayaan masyarakat terhadap sekolah akan menjadi lebih besar yang pada akhirnya bantuan sekolah pun akan menjadi lebih besar.

c. Dalam melaksanakan semua itu guru harus melaksanakan kode etiknya. Kode etik guru merupakan seperangkat aturan atau ramburambu hyang diikuti dan tidak boleh dilanggar oleh guru. Kode etik mengatur guru untuk menjadi manusia terpuji di mata masyarakat. Karena kode etik juga merupakan cerminan kehendak masyarakat terhadap guru, maka menjadi suatu kewajiban guru untuk melaksanakan atau mengikutinya.

Kompetensi sosial guru adalah kemampuan guru untuk mempersiapkan peserta didik menjadi anggota masyarakat yang baik serta kemampuan unutk mendidik, membimbing masyarakat dalam menghadapi kehidupan di masa yang akan datang.

Adapun peran guru di masyarakat dalam kaitannya dengan kompetensi sosial dapat diuraikan sebagai berikut :

1) Guru sebagai Petugas Kemasyarakatan

Sebagaimana telah dikemukakan di atas bahwa guru memegang peranan sebagai wakil masyarakat yang representative sehingga jabatan guru sekaligus merupakan jabatan kemasyarakatan. 
Guru bertugas membina masyarakat agar masyarakat berpastisipasi dalam pembangunan. Untuk melaksanakan tugas itu, guru harus memiliki kompetensi sebagai berikut. ${ }^{37}$

a) Aspek normatif kependidikan, yaitu untuk menjadi guru yang baik tidak cukup digantungkan kepada bakat, kecerdasan, kecakaoan saja, tetapi juga harus beritikad baik sehingga hal ini menyatu dengan norma yang dijadikan landasan dalam melaksanakan tugasnya.

b) Pertimbangan sebelum memilih jabatan guru

c) Mempunyai program meningkatkan kemajuan masyarakat dan kemajuan pendidikan.

2) Guru di Mata Masyarakat

Dalam pandangan masyarakat guru memiliki tempat tersendiri karena fakta menunjukkan bahwa ketika seorang guru berbuat senonoh, menyimpang dari ketentuan atau kaidah-kaidah masyarakat dan menyimpang dari apa yang diharaokan masyarakat, langsung saja masyarakat memberikan suara sumbang kepada guru itu. Kenakalan anak yang kini menggenjala di berbagai tempat, sering pula tanggungjawabnya di tudingkan kepada guru sepenuhnya dan sering pula dilupakan apa yang dilihat, didengar anak serta pergaulan anak dalam kehidupan masyarakat sehari-hari.

Dalam kedudukan seperti itu, guru tidak lagi dipandang sebagai pengajar di kelas, tapi darinya diharapkan pula tampil sebagai pendidik, bukan saja terhadap peserta didiknya di kelas, namun juga sebagai pendidik di masyarakat yang seyogyanya memberikan teladan yang baik kepada masyarakat.

Demikianlah atas dasar analisis sepintas ternyata kedudukan guru bukan hanya terbatas pada keempat dinding kelas di sekolah, bergeser jauh menembus batas halaman sekolah dan berada langsung di tengah-tengah masyarakat.Untuk itu, guru harus memiliki kompetensi sebagai berikut.

a) Mampu berkomunikasi dengan masyarakat

b) Mampu bergaul dan melayani masyarakat dengan baik

c) Mampu mendorong dan menunjang kreativitas masyarakat

d) Menjaga emosi dan perilaku yang kurang baik

4. Karakteristik Kompetensi Sosial

Karakteristik guru yang memiliki kesadaran sosial adalah berkomunikasi secara santun dan bergaul secara efektif. Suharsimi

${ }^{37}$ Mulyasa, Op Cit., h. 179. 
Arikunto mengemukakan, kompetensi sosial mengharuskan guru memiliki kemampuan komunikasi dengan siswa. ${ }^{38}$

a. Berkomunikasi Secara Santun

Made Pidarta dalam bukunya Landasan Kependidikan, menuliskan pengertian komunikasi adalah proses penyampaian pikiran dan perasaan seseorang kepada orang lain atau sekelompok orang. Ada sejumlah alat yang dapat dipakai mengadakan komunikasi. Alat dimaksud adalah sebagai berikut:

Melalui pembicaraan dengan segala macam nada seperti berbisik-bisik, halus, kasar, dan keras bergantung kepada tujuan pembicaraan dan sifat orang yang berbicara.

Melalui mimik, seperti raut muka, pandangan, dan sikap. Dengan lambang, contohnya ialah bicara isyarat untuk orang tuna rungu, menempelkan telunjuk di depan mulut, menggelengkan kepala, menganggukkan kepala, membentuk huruf "O" dengan tujuan, dengan tangan dan sebagainya.

Dengan alat-alat, yaitu alat-alat eletronik, seperti radio, televisi, telepon dan sejumlah media cetak seperti, buku, majalah, surat kabar, brosur, dan sebagainya. ${ }^{39}$

Empat alat di atas bisa digunakan guru ketika proses pembelajaran berlangsung.

Dengan adanya komunikasi dalam pelaksanaan proses pembelajaran berarti bahwa guru memberikan dan membangkitkan kebutuhan sosial siswa. Siswa akan merasa bahagia karena adanya perhatian yang diberikan guru sehingga dapat meningkatkan motivasi belajar siswa.

b. Bergaul Secara Efektif

Menurut Musaheri, bergaul secara efektif mencakup mengembangkan hubungan secara efektif dengan siswa yang memiliki ciri; mengembangkan hubungan dengan prinsip saling menghormati, mengembangkan hubungan berasakan asah, asih, dan asuh. Sedangkan ciri bekerja sama dengan prinsip ketebukaan, saling memberi dan menerima. ${ }^{40}$

Dari pernyataan di atas, jelas bahwa dalam pelaksanaan proses pembelajaran, guru memang harus memperhatikan pergaulan yang efektif dengan siswa. Hal tersebut dapat memotivasi siswa untuk lebih giat belajar.

\footnotetext{
${ }^{38}$ Suharsimi Arikunto, Manajemen Pengajaran Secara Manusiawi, hal. 239.

${ }^{39}$ Ibid, h. 239.

${ }^{40}$ Musaheri, ke-PGRI-an, (Jogjakarta, DIVA Press, 2009), hal. 203.
} 
Sedangkan menurut Rubin Adi Abraham kompetensi sosial guru memiliki ciri diantaranya, memiliki pengetahuan tentang hubungan antar manusia, menguasai psikologi sosial, dan memiliki keterampilan bekerjasama dalam kelompok. ${ }^{41}$

c. Memiliki Pengetahuan Tentang Hubungan Antar Manusia

Telah disinggung sebelumnya bahwa guru harus memiliki pengetahuan antar manusia. Hal ini terkadang disebut dengan interaksi sosial. Menurut $\mathrm{H}$. Bonner sebagaimana dikutip oleh $\mathrm{H}$. Ahmadi bahwa interaksi sosial adalah suatu hungan antar dua individu atau lebih dimana kelakuan individu yang satu mempengaruhi, mengubah atau memperbaiki kelakuan incividu yang lain dari sebaliknya. ${ }^{42}$

d. Menguasai Psikologi Sosial

Proses pembelajaran berkaitan erat dengan psikologi sosial. Dalam kehidupan sehari-hari, di lingkungan belajar mengajar terjadi interaksi sosial. Interaksi dilakukan oleh guru dan siswa baik di dalam atau luar kelas. Interaksi tersebut akan mendukung terhadap kelancaran proses pembelajaran di sekolah.

Perubahan pada tingkah laku dipengaruhi oleh interaksi sosial. Dan hal ini juga berlangsung dalam proses pembelajaran. Sehingga pembelajaran dapat terlaksana secara efektif dan menarik dari adanya interaksi guru dan siswa.

Dengan demikian, penguasaan psikologi sosial menjadi salah satu kriteria guru yang memiliki kompetensi sosial. Guru harus memahami pola tingkah laku siswa. Sehingga interaksi guru dan siswa dapat berjalan dengan lancar. Guru dapat dengan mudah mengetahui permasalahan yang terjadi kepada siswa. Pada akhirnya, guru akan membantu siswa untuk memecahkan masalah yang mengganggu terhadap kelancaran belajar.

e. Memiliki Keterampilan Bekerjasama dalam Kelompok.

Berkaitan dengan pemberian pemahaman kepada siswa, guru juga dituntut untuk memiliki keterampilan bekerja sama dalam kelompok. Sehingga guru dapat mengembangkan keterampilannya dalam pembelajaran. Kemampuan guru tersebut dapat meningkatkan semangat belajar siswa dan membangun rasa percaya diri bagi siswa.

Pernyataan di atas sesuai dengan pendapat Robert E. Slavin yang mengatakan bahwa akibat positif yang dapat mengembangkan hubungan antar kelompok adalah adanya penerimaan terhadap

\footnotetext{
${ }^{41}$ Abu Ahmadi, Sosiologi Pendidikan, (Jakarta: PT. Rineka Cipta, 2004), hal. 44

${ }^{42}$ Ibid.
} 
teman sekelas yang lemah dalam bidang akademik, dan meningkatkan rasa harga diri. ${ }^{43}$

Demikianlah kriteria yang harus dimiliki oleh guru yang memiliki kompetensi sosial. Selain karakteristik yang disebutkan oleh Musaheri dan Rubin Adi, guru juga harus memiliki kemampuan memberikan umpan balik kepada siswa dan turun tangan langsung ketika siswa mengalami masalah. ${ }^{44}$

5. Guru

Guru adalah pendidik, yaitu orang dewasa yang bertanggung jawab memberi bimbingan atau bantuan kepada anak didik dalam perkembangan jasmani dan rohaninya agar mencapai kedewasaannya, mampu berdiri sendiri dapat melaksanakan tugasnya sebagai makhluk Allah khalifah di muka bumi, sebagai makhluk sosial dan individu yang sanggup berdiri sendiri. ${ }^{45}$

Menurut Peraturan Pemerintah Guru adalah jabatan fungsional, yaitu kedudukan yang menunjukkan tugas, tanggung jawab, wewenang, dan hak seorang PNS dalam suatu organisasi yang dalam pelaksanaan tugasnya didasarkan keahlian atau keterampilan tertentu serta bersifat mandiri.

Menurut Keputusan Men.Pan Guru adalah Pegawai Negeri Sipil yang diberi tugas, wewenang dan tanggung jawab oleh pejabat yang berwenang untuk melaksanakan pendidikan di sekolah.

Menurut Undang-undang No. 14 tahun 2005 Guru adalah pendidik profesional dengan tugas utama mendidik, mengajar, membimbing, mengarahkan, melatih, menilai, dan mengevaluasi peserta didik pada pendidikan anak usia dini jalur pendidikan formal, pendidikan dasar, dan pendidikan menengah.

Para pakar pendidikan di Barat telah melakukan penelitian tentang peran guru yang harus dilakoni. Peran guru yang beragam telah diidentifikasi dan dikaji oleh Pullias dan Young, Manan serta Yelon dan Weinstein.

Adapun peran-peran tersebut adalah sebagai berikut $:^{46}$

a. Guru Sebagai Pendidik

43 Robert E. Slavin, Cooperative Learning; Teori Riset dan Praktik, penerjemah: Nurulita (Bandung: Nusa Media, 2008), hal. 5.

${ }^{44}$ Muhammad Ali, Guru dalam Proses Belajar Mengajar, (Bandung: Sinar Baru alGensindo, 2008), hal. 7.

45 Jaliman, op cit., h.1.

${ }^{46}$ Ibid 
Guru adalah pendidik, yang menjadi tokoh, panutan dan identifikasi bagi para peserta didik, dan lingkungannya. Oleh karena itu, guru harus memiliki standar kualitas tertentu, yang mencakup tanggung jawab, wibawa, mandiri dan disiplin. Peran guru sebagai pendidik (nurturer) berkaitan dengan meningkatkan pertumbuhan dan perkembangan anak untuk memperoleh pengalamanpengalaman lebih lanjut seperti penggunaan kesehatan jasmani, bebas dari orang tua, dan orang dewasa yang lain, moralitas tanggungjawab kemasyarakatan, pengetahuan dan keterampilan dasar, persiapan.untuk perkawinan dan hidup berkeluarga, pemilihan jabatan, dan hal-hal yang bersifat personal dan spiritual. Oleh karena itu tugas guru dapat disebut pendidik dan pemeliharaan anak. Guru sebagai penanggung jawab pendisiplinan anak harus mengontrol setiap aktivitas anak-anak agar tingkat laku anak tidak menyimpang dengan norma-norma yang ada.

b. Guru Sebagai Pengajar

Peranan guru sebagai pengajar dan pembimbing dalam kegiatan belajar peserta didik dipengaruhi oleh berbagai factor, seperti motivasi, kematangan, hubungan peserta didik dengan guru, kemampuan verbal, tingkat kebebasan, rasa aman dan keterampilan guru dalam berkomunikasi. Jika factor-faktor di atas dipenuhi, maka melalui pembelajaran peserta didik dapat belajar dengan baik. Guru harus berusaha membuat sesuatu menjadi jelas bagi peserta didik dan terampil dalam memecahkan masalah.

Ada beberapa hal yang harus dilakukan oleh seorang guru dalam pembelajaran, yaitu: Membuat ilustrasi, Mendefinisikan, Menganalisis, Mensintesis, Bertanya, Merespon, Mendengarkan, Menciptakan kepercayaan, Memberikan pandangan yang bervariasi, Menyediakan media untuk mengkaji materi standar, Menyesuaikan metode pembelajaran, Memberikan nada perasaan.

Agar pembelajaran memiliki kekuatan yang maksimal, guruguru harus senantiasa berusaha untuk mempertahankan dan meningkatkan semangat yang telah dimilikinya ketika mempelajari materi standar.

c. Guru Sebagai Pembimbing

Guru dapat diibaratkan sebagai pembimbing perjalanan, yang berdasarkan pengetahuan dan pengalamannya bertanggung jawab atas kelancaran perjalanan itu. Dalam hal ini, istilah perjalanan tidak hanya menyangkut fisik tetapi juga perjalanan mental, emosional, kreatifitas, moral dan spiritual yang lebih dalam dan kompleks. 
Sebagai pembimbing perjalanan guru memerlukan kompetensi yang tinggi untuk melaksanakan empat hal berikut:

1) Guru harus merencanakan tujuan dan mengidentifikasi kompetensi yang hendak dicapai.

2) Guru harus melihat keterlibatan peserta didik dalam pembelajaran, dan yang paling penting bahwa peserta didik melaksanakan kegiatan belajar itu tidak hanya secara jasmaniah, tetapi mereka harus terlibat secara psikologis.

3) Guru harus memaknai kegiatan belajar.

4) Guru harus melaksanakan penilaian.

d. Guru Sebagai Pemimpin

Guru diharapkan mempunyai kepribadian dan ilmu pengetahuan. Guru menjadi pemimpin bagi peserta didiknya. Ia akan menjadi imam.

e. Guru Sebagai Pengelola Pembelajaran

Guru harus mampu menguasai berbagai metode pembelajaran. Selain itu, guru juga dituntut untuk selalu menambah pengetahuan dan keterampilan agar supaya pengetahuan dan keterampilan yang dirnilikinya tidak ketinggalan jaman.

f. Guru Sebagai Model dan Teladan

Guru merupakan model atau teladan bagi para peserta didik dan semua orang yang menganggap dia sebagai guru. Terdapat kecenderungan yang besar untuk menganggap bahwa peran ini tidak mudah untuk ditentang, apalagi ditolak. Sebagai teladan, tentu saja pribadi dan apa yang dilakukan guru akan mendapat sorotan peserta didik serta orang disekitar lingkungannya yang menganggap atau mengakuinya sebagai guru. Ada beberapa hal yang harus diperhatikan oleh guru: sikap dasar, bicara dan gaya bicara, kebiasaan bekerja, sikap melalui pengalaman dan kesalahan, pakaian, hubungan kemanusiaan, proses berfikir, perilaku neurotis, selera, keputusan, kesehatan, gaya hidup secara umum.

Perilaku guru sangat mempengaruhi peserta didik, tetapi peserta didik harus berani mengembangkan gaya hidup pribadinya sendiri.

Guru yang baik adalah yang menyadari kesenjangan antara apa yang diinginkan dengan apa yang ada pada dirinya, kemudian menyadari kesalahan ketika memang bersalah. Kesalahan harus diikuti dengan sikap merasa dan berusaha untuk tidak mengulanginya.

g. Sebagai Anggota Masyarakat

Peranan guru sebagai komunikator pembangunan masyarakat. Seorang guru diharapkan dapat berperan aktif dalam pembangunan 
disegala bidang yang sedang dilakukan. Ia dapat mengembangkan kemampuannya pada bidang-bidang dikuasainya. Guru perlu juga memiliki kemampuan untuk berbaur dengan masyarakat melalui kemampuannya, antara lain melalui kegiatan olah raga, keagamaan dan kepemudaan. Keluwesan bergaul harus dimiliki, sebab kalau tidak pergaulannya akan menjadi kaku dan berakibat yang bersangkutan kurang bisa diterima oleh masyarakat.

h. Guru sebagai administrator

Seorang guru tidak hanya sebagai pendidik dan pengajar, tetapi juga sebagai administrator pada bidang pendidikan dan pengajaran. Guru akan dihadapkan pada berbagai tugas administrasi di sekolah. Oleh karena itu seorang guru dituntut bekerja secara administrasi teratur. Segala pelaksanaan dalam kaitannya proses belajar mengajar perlu diadministrasikan secara baik. Sebab administrasi yang dikerjakan seperti membuat rencana mengajar, mencatat hasil belajar dan sebagainya merupakan dokumen yang berharga bahwa ia telah melaksanakan tugasnya dengan baik.

i. Guru Sebagai Penasehat

Guru adalah seorang penasehat bagi peserta didik juga bagi orang tua, meskipun mereka tidak memiliki latihan khusus sebagai penasehat dan dalam beberapa hal tidak dapat berharap untuk menasehati orang.

Peserta didik senantiasa berhadapan dengan kebutuhan untuk membuat keputusan dan dalam prosesnya akan lari kepada gurunya. Agar guru dapat menyadari perannya sebagai orang kepercayaan dan penasihat secara lebih mendalam, ia harus memahami psikologi kepribadian dan ilmu kesehatan mental.

j. Guru Sebagai Pembaharu (Inovator)

Guru menerjemahkan pengalaman yang telah lalu ke dalam kehidupan yang bermakna bagi peserta didik. Dalam hal ini, terdapat jurang yang dalam dan luas antara generasi yang satu dengan yang lain, demikian halnya pengalaman orang tua memiliki arti lebih banyak daripada nenek kita. Seorang peserta didik yang belajar sekarang, secara psikologis berada jauh dari pengalaman manusia yang harus dipahami, dicerna dan diwujudkan dalam pendidikan.

Tugas guru adalah menerjemahkan kebijakan dan pengalaman yang berharga ini kedalam istilah atau bahasa moderen yang akan diterima oleh peserta didik. Sebagai jembatan antara generasi tua dan genearasi muda, yang juga penerjemah pengalaman, guru harus menjadi pribadi yang terdidik.

k. Guru Sebagai Pendorong Kreatifitas 
Kreativitas merupakan hal yang sangat penting dalam pembelajaran dan guru dituntut untuk mendemonstrasikan dan menunjukkan proses kreatifitas tersebut. Kreatifitas merupakan sesuatu yang bersifat universal dan merupakan cirri aspek dunia kehidupan di sekitar kita. Kreativitas ditandai oleh adanya kegiatan menciptakan sesuatu yang sebelumnya tidak ada dan tidak dilakukan oleh seseorang atau adanya kecenderungan untuk menciptakan sesuatu.

Akibat dari fungsi ini, guru senantiasa berusaha untuk menemukan cara yang lebih baik dalam melayani peserta didik, sehingga peserta didik akan menilaianya bahwa ia memang kreatif dan tidak melakukan sesuatu secara rutin saja. Kreativitas menunjukkan bahwa apa yang akan dikerjakan oleh guru sekarang lebih baik dari yang telah dikerjakan sebelumnya.

1. Guru Sebagai Emansipator

Dengan kecerdikannya, guru mampu memahami potensi peserta didik, menghormati setiap insan dan menyadari bahwa kebanyakan insan merupakan "budak" stagnasi kebudayaan. Guru mengetahui bahwa pengalaman, pengakuan dan dorongan seringkali membebaskan peserta didik dari "self image" yang tidak menyenangkan, kebodohan dan dari perasaan tertolak dan rendah diri. Guru telah melaksanakan peran sebagai emansipator ketika peserta didik yang dicampakkan secara moril dan mengalami berbagai kesulitan dibangkitkan kembali menjadi pribadi yang percaya diri.

\section{m. Guru Sebagai Evaluator}

Evaluasi atau penilaian merupakan aspek pembelajaran yang paling kompleks, karena melibatkan banyak latar belakang dan hubungan, serta variable lain yang mempunyai arti apabila berhubungan dengan konteks yang hampir tidak mungkin dapat dipisahkan dengan setiap segi penilaian. Teknik apapun yang dipilih, dalam penilaian harus dilakukan dengan prosedur yang jelas, yang meliputi tiga tahap, yaitu persiapan, pelaksanaan dan tindak lanjut.

n. Guru Sebagai Kulminator

Guru adalah orang yang mengarahkan proses belajar secara bertahap dari awal hingga akhir (kulminasi). Dengan rancangannya peserta didik akan melewati tahap kulminasi, suatu tahap yang memungkinkan setiap peserta didik bisa mengetahui kemajuan belajarnya. Di sini peran kulminator terpadu dengan peran sebagai evaluator. 
Guru sejatinya adalah seorang pribadi yang harus serba bisa dan serba tahu. Serta mampu mentransferkan kebisaan dan pengetahuan pada muridnya dengan cara yang sesuai dengan perkembangan dan potensi anak didik.

Begitu banyak peran yang harus diemban oleh seorang guru. Peran yang begitu berat dipikul di pundak guru hendaknya tidak menjadikan calon guru mundur dari tugas mulia tersebut. Peranperan tersebut harus menjadi tantangan dan motivasi bagi calon guru. Dia harus menyadari bahwa di masyarakat harus ada yang menjalani peran guru. Bila tidak, maka suatu masyarakat tidak akan terbangun dengan utuh. Penuh ketimpangan dan akhirnya masyarakat tersebut bergerak menuju kehancuran.

\section{Kesimpulan}

Adapun Manajemen Kepala Madrasah Dalam Meningkatkan Kompetensi Sosial Guru, yaitu dengan mendengarkan ide / saran dari para guru, Sosialisasi, mengemukakan keinginan dan menjelaskan keinginan, memberikan masukan dan berusaha memecahkan masalah guru, Membagi tugas secara bersama (tidak monopoli), memberikan teladan, bertindak sesuai dengan kemampuan guru, memberikan perhatian yang lebih terhadap yang rajin, dan Mengikuti pelatihan berkaitan dengan kompetensi sosial guru.

Secara keseluruhan dan umum kinerja guru yang menjadi kendala adalah cara mengajar guru kurang disukai/bahkan tidak disukai, bimbingan dan penyuluhan dari guru kurang maksimal, penguasaan guru akan ilmu yang harus disampaikan kurang, cara penyampaian materi yang monoton dan kurang variatif, kurangnya pemahaman guru tentang psikologi anak, perhatian guru tentang latar belakang dan kebutuhan anak kurang, kurang adanya konsep perencanaan yang baik dalam penyusunan program-program untuk memajukan lembaga yang ditanganinya, kepribadian guru yang kurang matang, dan minimnya kreatifitas dan inovasi untuk mengatasi berbagai hambatan yang terjadi dalam lembaga.

Dengan adanya kombinasi antara kompetensi sosial kepala madrasah dengan manajemennya dan juga kompetensi sosial guru maka mutu pendidikan Islam dapat ditingkatkan, dan seluruh madrasah menjadi bergengsi dan membuat output yang berkualitas. 


\section{Daftar Pustaka}

Ahmadi, Abu. Sosiologi Pendidikan, Jakarta: PT. Rineka Cipta, 2004.

Ali, Muhammad. Guru dalam Proses Belajar Mengajar, Bandung: Sinar Baru alGensindo, 2008.

Alma, Buchari. Guru Professional (Menguasai Metode dan Terampil Mengajar), Bandung, Alfabeta, 2009.

Arifin, M. Kapita Selekta Pendidikan (Islam dan Umum), cet. III., Bandung: Bumi Aksara, 1995.

Arikunto, Suharsimi. Prosedur Penelitian Suatu Pendekatan Praktek. Jakarta : Rineka Cipta, 2002.

Bachrie, Namira Suade, Hubungan Jenis Sekolah dalam Kesadaran Sosial, Jurnal FPSI UI, 2009.

Burhan. Analisis Data Penelitian Kualitatif. Jakarta: PT Rahagrafindo Persada, 2003.

Burhanuddin, Analisis Administrasi Manajemen dan Kepemimpinan Pendidikan, cet. I., Jakarta: Bumi Aksara, 1994.

Chang, William. Pengantar Teologi Moral, Jakarta: 2001.

Colby, Jeanette and Miske Witt, Defining Quality in Education, Working paper of

Education Section, program division, UNICEF, New York 2000.

Damser, Pengantar Sosiologi Pendidikan, Jakarta : Kencana, 2008.

Dokumen M'Ts Nurul Kamal Sambirejo 2006.

Fattah, Nanang. Konsep Manajemen Berbasis Sekolah (MBS) dan Dewan Sekolah, cet. I.,(Bandung: Pustaka Bani Quraisy, 2004.

Hariandja, Marihot T. E, Manajemen Sumber Daya Manusia, PT Gramedia Widiasarana Indonesia, Jakarta 2005.

Harvey, James. the school principal as leader: guiding schools to better teaching and learning, the Wallace Foundation, 2013.

http://www.kompasiana.com/mustaqim.ode/menghalau-premanisme-denganmenumbuhkan-kesadaran-sosial_5528ea62f17e61c31d8b4592

http://mahdiannur.blogspot.com./2009/03/kopetensi-sosial-kemampuan

beradaptasi. html. di akses 9 Agustus 2016

Imam Muslim, Shabih Muslim.

Ishomuddin, Pendidikan Karakter, Jakarta: 1996.

Mangkunegara, Anwar Prabu. Manajemen Sumber Daya Manusia, PT Remaja Rosda Karya, Bandung, 2002.

Mulyasa, Manajemen dan Kepemimpinan Kepala Sekolah, Jakarta:Penerbit Bumi Aksara, 2011.

Moleong. Lexy J. Metodologi Penelitian Kualitatif. Bandung: Remaja Rosdakarya, 2007.

Musaheri, ke-PGRI-an, Jogjakarta, DIVA Press, 2009. 
Nauli, Lidia. Kesadaran Sosial Membentuke Solidaritas Sosial, Jurnal. Undip. 2015.

Nawawi, Hadari. Manajemen Sumber Daya Manusia Untuk Bisnis Yang Kompetitif,

Cetakan Ke-4, Gajah Mada Univercity Press, Yogyakarta,2005.

Nurhadi, Muljani A. Paradigma Baru Pengelolaan Pendidikan di Daerah Dalam Rangka Desentralisasi Pendidikan, Yogyakarta: Pustaka Pelajar, 2002.

Padil, Moh. Sosiologi Pendidikan, Yogyakarta: UIN-Maliki Press, 2007.

Purwanto, M. Ngalim. Administrasi dan Supervisi Pendidikan, cet. V., Bandung: Remaja Rosda Karya, 1992.

Rivai, Veithzal. Manajemen Sumber Daya Manusia Untuk Perusahaan, Jakarta: Muria Kencana, 2004.

Rosyada, Dede. Paradigma Pendidikan Demokratis, Sebuah Model pelibatan Masyarakat dalam Pendidikan, Jakarta: Prenada Media, 2013. Creative Thinking, Kolom Rector UIN Syarif Hidayatullah, jakarta, Edisi 3 Mei 2015.

Sarwoto, Dasar-Dasar Organisasi dan Manajemen, Ghalia, Jakarta Indonesia, 2000.

Slavin, Robert E. Cooperative Learning; Teori Riset dan Praktik, penerjemah:

Nurulita. Bandung: Nusa Media, 2008.

Sugiyono. Metode Penelitian Administrasi. Bandung : Alfabeta, 2007.

Sudijono, Anas. Evaluasi Pendidikan. Jakarta : Raja Grafindo, 1996.

Saydam, Gouzali. Manajemen Sumber Daya Manusia (Human Resource) Suatu Pendekatan Mikro, Djanbatan, Jakarta, 2000.

Tilaar, Ace Suryadi. Analisis Kebijakan Pendidikan, Suatu Pengantar, Banduung: Remaja Rosdakarya, 1993.

Tim Penyusun KBBI, 1988 : 765

Wahjosumidjo, Kepemimpinan Kepala Sekolah, Jakarta:Penerbit PT RajaGrafindo, 1995.

Wegner, Social Awareness, Jurnal Sheldon. 1982. 
214 | Belajea : Jurnal Pendidikan Islam, Vol. 2, No. 02, 2017 